\title{
The effect of milk proteins and curd on serum Angiotensin Converting Enzyme activity and lipid profile in Wistar rats
}

\author{
L.V. Athiththan ${ }^{1}$, S.D. Jayaratne ${ }^{2}$, H. Peiris ${ }^{1 *}$ and S. Jayesekera ${ }^{3}$ \\ Department of Biochemistry, Faculty of Medical Sciences, University of Sri Jayewardenepura, Gangodawila, Nugegoda. \\ 2 Department of Medicine, Faculty of Medical Sciences, University of Sri Jayewardenepura, Gangodawila, Nugegoda. \\ 3 Animal Centre, Medical Research Institute, Colombo.
}

Revised: 06 February 2009; Accepted: 20 March 2009

\begin{abstract}
Fermented milk and milk proteins have shown beneficiary health effects in humans. Angiotensin-II, which is formed from angiotensin-I by Angiotensin Converting Enzyme (ACE), plays a major role in regulating the blood pressure in humans and animals. Two experiments were carried out to determine the effects of prolonged consumption of milk proteins (casein \& whey) in comparison with fermented milk (curd) on serum ACE activity and lipid profiles in Wistar rats. In experiment I, test groups were given $2 \mathrm{~mL}$ of hydrolysed casein or curd, whilst in experiment II, test groups received $2 \mathrm{~mL}$ whey and controls received $2 \mathrm{~mL}$ of water. The percentage differences obtained for individual animals were analysed after eight weeks. Casein hydrolysate fed group had a $4.3 \%$ reduction in serum ACE activity when compared with $3.5 \%$ reduction in curd hydrolysate fed group. The mean percentage difference of ACE showed significantly lower values $(p<0.05)$ in both casein and curd fed group when compared with the control. A greater reduction in serum total cholesterol was noted in the curd fed group $(7.3 \%)$ when compared with the whey fed group $(5.4 \%)$ and the casein treated group $(0.8 \%)$. The mean percentage difference was significant $(\mathrm{p}<0.05)$ only in the curd and whey treated groups. There was no significant difference in feed intake, body weight, serum high density lipoprotein cholesterol and triglycerides, between the treated groups and the control groups. This indicates that both casein and curd have the effect of lowering serum ACE activity.
\end{abstract}

Keywords: Angiotensin Converting Enzyme activity, casein, fermented milk, lipid profile, whey.

\section{INTRODUCTION}

Milk is a complete nutritional natural food of all mammals and dairy products form a major part of human food. Dairy products and especially fermented milk have been identified as functional foods ${ }^{1}$.
The protein fraction of milk is composed of $80 \%$ casein, whey proteins ( $\alpha$-lactalbumin and $\beta$-lactoglobulin) and immunoglobulins ${ }^{1,2}$. Casein $\left(\alpha_{\mathrm{s} 1}, \alpha_{\mathrm{s} 2,}, \beta \text { and } \kappa\right)^{2,3}$ forms complexes called micelles with calcium. Milk proteins also contain biologically active peptides. These peptides are formed by the enzymatic hydrolysis of proteins or by the proteolytic activity of the bacteria during microbial fermentation. Microorganisms can form caseino phospho peptides from the protein, casein, and other peptides as well. These peptides survive in the intestine. In-vitro studies indicate that milk peptides have an inhibitory effect on Angiotensin Converting Enzyme (ACE) activity $^{4,5}$. Several inhibitors of Angiotensin-I (ANG I) converting enzyme have been isolated from milk protein hydrolysates and this has been validated by in-vitro assays ${ }^{4,5}$. Anti hypertensive activity of fermented milk has also been reported and it is believed that specific milk proteins in fermented milk has ACE inhibiting activity ${ }^{6,7}$. Many other peptides also have inhibitory effects on ACE activity $^{5}$.

ACE plays a major role in regulating the blood pressure in humans and animals ${ }^{7}$. This enzyme catalyses the conversion of ANG I to ANG II ${ }^{8}$ which is a vasopressor agent that increases the blood pressure by promoting vasoconstriction by directly acting on vascular smooth muscle and increasing the arterial tone by interacting with the sympathetic nervous system both peripherally and centrally ${ }^{9}$. Pharmacological preparations such as $\beta$-blockers, calcium-channel blockers, and ACE inhibitors are used to control hypertension ${ }^{10}$. However, these drugs are relatively expensive and have many side effects. If the natural product consumed as food helps in reducing the blood pressure it would greatly benefit mankind. 
It has been reported that the acid producing organisms in fermented dairy products could prolong the life span of the consumer ${ }^{1}$. Fermented foods contain live bacteria that influence the chemical composition of the fermented product, especially milk proteins which result in the availability of amino acids and milk lipids which provide the short chain fatty acids ${ }^{1}$.

Lactose intolerance is a common health problem among Asian adults ${ }^{1}$ where $95 \%$ of certain Asian people show a more or less advanced low lactase activity ${ }^{11}$. Fermented milk is of high nutritive value and is commonly available as a source of natural protein.

The hydrolysed form of casein and curd used in in-vitro studies had a higher inhibiting activity on ACE than fresh curd, milk and whey. This indicates that enzymatic hydrolysis provides smaller peptides that have a stronger ACE inhibiting activity. Several in-vitro studies $^{4-6}$ and few in-vivo ${ }^{7}$, including limited human studies $^{12}$ have been performed to validate these effects of the peptides. Hence hydrolysed casein and curd were used in our study.

Very limited work has been reported in in-vivo models for ACE inhibiting activity and the lipid profile being measured together. The present study would add new information to the available literature.

An animal study was carried out on male Wistar rats to test the effects of casein hydrolysates, whey or curd (obtained from a local dairy product) hydrolysates, on serum ACE activity and lipid profile.

As caseino phospho peptides (casein hydrolysates) isolated from milk are not commonly consumed by humans, whole curd hydrolysate was used in the animal experiment.

\section{METHODS AND MATERIALS}

A study was carried out using two different experiments to study the effect of casein, whey and curd on male Wistar rats. Ethical clearance was obtained from the Ethical Committee, Medical Research Institute, Colombo.

In experiment I, 24 male Wistar rats ( 8 wks old) were randomly allocated into 3 groups, and in experiment II 14 male Wistar rats (14 wks old) were randomly divided into 2 groups. Fourteen weeks old rats were selected in the $2^{\text {nd }}$ experiment to avoid the increase of value with age for the serum parameters assayed. The pre experimental characters of animals such as body weight (BW), ACE activity, total cholesterol (TC), high density lipoprotein cholesterol (HDL), and triglycerides (TG) did not show any significant differences $(p>0.2)$ between the test and control groups. Each animal in the group was identified by the colour tagging method. They were provided with WHO standard diet, water ad libitum and housed in rat cages under standard condition.

In experiment I each rat in the test group was fed with either $2 \mathrm{~mL}$ of casein or $2 \mathrm{~mL}$ of curd hydrolysates and the animals in the control group received $2 \mathrm{~mL}$ of drinking water every morning via gastric intubation for a period of $8 \mathrm{wks}$. In experiment II each rat in the test group was given $2 \mathrm{~mL}$ of whey, while the animals in the control group received $2 \mathrm{~mL}$ of drinking water daily in the morning via gastric intubation for a period of $8 \mathrm{wks}$.

The oral dose of $2.16 \mathrm{~g} / 2 \mathrm{~mL}$ of casein or curd hydrolysates, which was equivalent to an average intake of $80 \mathrm{~g}$ curd by an adult human, was administered via gastric intubation. This animal dose was calculated according to a standard drug dose chart conversion table which gives a conversion factor of 0.018 for $200 \mathrm{~g}$ body weight of rats. The human consumption of $80 \mathrm{~g}$ was given to rats having a mean body weight of $300 \mathrm{~g}$.

The casein sample was prepared by centrifuging the milk at $17,000 \mathrm{~g}$ at $4^{\circ} \mathrm{C}$ for $20 \mathrm{~min}$. The fat in the top layer was removed and was filtered through a muslin cloth and the filtrate was re-centrifuged to ensure the maximal removal of fat $^{13}$. Acetic acid was added to the filtrate to bring the $\mathrm{pH}$ slightly below the iso-electric $\mathrm{pH} 4.6$ and the $\mathrm{pH}$ was then adjusted to 4.6 using sodium acetate. The weak acid base buffer increases the stability of the precipitate. The casein precipitate was filtered through a muslin cloth and washed several times with water and the precipitate was dried at $45^{\circ} \mathrm{C}$ in an air flowing oven ${ }^{14}$. The filtrate obtained was centrifuged at $4000 \mathrm{rpm}$ for 10 min to remove any remaining casein and the whey was separated.

The casein sample isolated from milk or a locally manufactured curd sample which was produced using two bacteria species viz., Streptococcus thermophillus and Lactobacillus bulgaricus as the starter culture was subjected to sequential enzymatic digestion. For the preparation of $100 \mathrm{~mL}$ hydrolysates, $108 \mathrm{~g}$ casein was dissolved in $25 \mathrm{~mL}$ hot water and $108 \mathrm{~g}$ curd was dissolved in $25 \mathrm{~mL}$ distilled water and they were subjected to sequential enzymatic digestion after cooling. Pepsin was added at $\mathrm{pH} 1.5(1 \mathrm{~N} \mathrm{HCl})$ and incubated at $37^{\circ} \mathrm{C}$ for $24 \mathrm{~h}$ in a shaking water bath. The $\mathrm{pH}$ was adjusted to $7.8(1 \mathrm{~N}$ $\mathrm{NaOH})$ and digested with pancreatin and trypsin for $24 \mathrm{~h}$ at $37^{\circ} \mathrm{C}$. The samples were mixed and the variation in the $\mathrm{pH}$ due to the product formed was monitored at time to 
time and readjusted to obtain the optimum $\mathrm{pH}$ for their activity.

The samples were heated to $80^{\circ} \mathrm{C}$ for $5 \mathrm{~min}$ to inactivate the enzyme activity ${ }^{5}$ and $\mathrm{pH}$ was adjusted to 7 . The samples were diluted to $100 \mathrm{~mL}$ to obtain the final concentration of $2.16 \mathrm{~g} / 2 \mathrm{~mL}$ which was used for oral feeding. The hydrolysates were stored at $-20^{\circ} \mathrm{C}$ for a week.

Blood samples were collected from the lateral tail vein into vials without anticoagulant from anaesthetised rats after 12-14 $\mathrm{h}$ fasting. The animals were anaesthetised using ether. Samples were collected at the beginning ( 0 wk) and at 4 and 8 wks during the experiment.

Blood samples were centrifuged after $1 / 2 \mathrm{~h}$ and serum samples were separated and stored at $-20^{\circ} \mathrm{C}$ pending analysis.

The laboratory analysis was performed within $2 \mathrm{~d}$ of collection of samples for ACE activity, TC, HDL and TG. The LDL cholesterol concentration was not determined.

The serum ACE activity was measured using some modification in the incubation time and volume to the original Cushman DW and Cheung HS ${ }^{4,5,7}$ method in order to increase the efficiency of the assay.

ACE catalyses the hydrolysis of Hippuryl-LHistidyl-L-Leucine (HHL-sigma product No H-1635) to hippuric acid. HHL buffer $(20 \mu \mathrm{L})$ was freshly prepared by dissolving in HEPES sodium salt (sigma product No H-7006) $\mathrm{HCl}$ buffer and was incubated at $37^{\circ} \mathrm{C}$ for $5 \mathrm{~min}$. A serum sample of $50 \mu \mathrm{L}$ or $\mathrm{ACE}(0.33$ units $/ \mathrm{mL})$ enzyme solution was added and incubated at $37^{\circ} \mathrm{C}$ for $15 \mathrm{~min}$. The volume of serum and enzyme concentration was modified in order to improve the efficiency of ACE activity. $\mathrm{HCl}$ was added to inhibit the reaction and the supernatant was extracted into $2 \mathrm{~mL}$ of ethyl acetate. From the clear upper layer of each vial $1 \mathrm{~mL}$ was pipetted into test tubes and was placed in a boiling water bath for $20 \mathrm{~min}$ and $3 \mathrm{~mL}$ of de-ionized water was added after the ethyl acetate has evaporated. The hippuric acid formed was detected by recording the absorbance at $228 \mathrm{~nm}$ in a spectrophotometer.

Unit definition: One unit will produce $1.0 \mu$ mole of hippuric acid from HHL per min in $50 \mathrm{mM}$ HEPES and $300 \mathrm{mM} \mathrm{NaCl}$ at $\mathrm{pH} 8.3$ at $37^{\circ} \mathrm{C}$. Serum was analyzed for TC, HDL cholesterol, and TG using a commercial assay kit method (Accurex Biomedical Pvt. Ltd.).

The TC and TG were assayed using the enzymatic hydrolysis process. The HDL-cholesterol was assayed using HDL-cholesterol precipitating reagent containing phosphotungstic acid and magnesium chloride that precipitates chylomicrons, LDL and VLDL. HDL cholesterol remains in the supernatant.

Statistical analysis was carried out with Microsoft Excel and Student t-test was performed with SPSS. The $\mathrm{p}$ value $<0.05$ was considered to be significant. The percentage difference was calculated for individual animals for the parameters assayed and it was compared with the control values.

$\%$ differences $=\frac{\begin{array}{c}\text { Value at the end of } \\ \text { the experiment }\end{array}-\begin{array}{c}\text { Initial } \\ \text { value }\end{array}}{\text { Initial value }} \times 100$

\section{RESULTS}

The mean value of body weight and each blood parameters of animals were similar in all experimental groups except for ACE activity values obtained in curd hydrolysate treated groups in experiment I. The high standard deviation obtained for ACE activity may be due to the biological variation of individual animals (Table 1).

At the end of 8 weeks (Table 2), animals administered with casein had the highest reduction of $4.3 \%$ for the ACE activity when compared with the control. Furthermore, all the animals in the casein treated group had a lower ACE value than the initial value. The curd fed group also showed a reduction of $3.5 \%$ for the ACE activity. The percentage reduction was significant in both the casein and curd fed group when compared to the control. The control group showed an increase of $0.2 \%$ for the ACE activity. This indicates that after eight weeks the intake of casein and curd hydrolysates had significant reduction in ACE activity when compared with that of control.

The serum TC, TG, HDL cholesterol and BW values of animals in all test and control groups increased with their age as the experiment progressed. In the curd fed group the percentage increase in serum TC was lowest and was significantly different $(p=0.026)$ when compared with the control.

The whey fed group (Table 2) had a reduction of 3.2\% in the body weight, $0.7 \%$ in the ACE activity, 5.4\% in the $\mathrm{TC}$ and $4.5 \%$ reduction in the $\mathrm{TG}$ levels respectively. The percentage difference in serum TC showed a significantly lower value $(\mathrm{p}<0.036)$ when compared with the control. The other parameters assessed did not show any significant difference when compared with the control. 
Table 1: Effect of feeding casein and curd hydrolysates on serum ACE activity and lipid profiles of Wistar rats

\begin{tabular}{|c|c|c|c|c|c|c|}
\hline Experimental groups & Study period & ACE (Units/L) & $\mathrm{TC}(\mathrm{g} / \mathrm{dL})$ & HDL (g/dL) & TG (g/dL) & BW (g) \\
\hline \multirow[t]{3}{*}{ Casein $\dagger$} & 0 wks & $474.8 \pm 88.1$ & $79.0 \pm 2.1$ & $34.4 \pm 4.3$ & $207.8 \pm 33.9$ & $192.3 \pm 13.7$ \\
\hline & 4 wks & $463.7 \pm 86.4$ & $87.6 \pm 13.4$ & Not measured & $211.4 \pm 33.5$ & $354.4 \pm 14.6$ \\
\hline & 8 wks & $455.6 \pm 84.8$ & $93.0 \pm 9.7$ & $39.4 \pm 3.0$ & $228.3 \pm 33.8$ & $404.5 \pm 29.5$ \\
\hline \multirow[t]{3}{*}{ Curd $\dagger$} & $0 \mathrm{wks}$ & $439.6 \pm 108.4$ & $77.62 \pm 2.4$ & $33.3 \pm 4.3$ & $202.2 \pm 38.8$ & $195.0 \pm 11.5$ \\
\hline & 4 wks & $432.6 \pm 112.6$ & $84.6 \pm 2.7$ & Not measured & $207.7 \pm 35.8$ & $344.9 \pm 14.9$ \\
\hline & 8 wks & $426.1 \pm 112.1$ & $87.2 \pm 3.1$ & $40.9 \pm 1.9$ & $225.3 \pm 38.8$ & $400.8 \pm 22.5$ \\
\hline \multirow[t]{3}{*}{ Control I† } & 0 wks & $476.3 \pm 73.6$ & $79.5 \pm 12.3$ & $32.0 \pm 3.5$ & $208.2 \pm 41.8$ & $193.8 \pm 7.0$ \\
\hline & 4 wks & $482.3 \pm 68.5$ & $89.9 \pm 12.4$ & Not measured & $215.3 \pm 38.4$ & $348 \pm 10.8$ \\
\hline & 8 wks & $487.1 \pm 73.0$ & $94.8 \pm 13.6$ & $40.6 \pm 2.7$ & $232.9 \pm 40.0$ & $402.3 \pm 16.1$ \\
\hline \multirow[t]{2}{*}{ Whey* } & 0 wks & $450.1 \pm 98.6$ & $91.0 \pm 15.3$ & $41.5 \pm 4.0$ & $195.1 \pm 14.4$ & $404.3 \pm 18.9$ \\
\hline & 8 wks & $450.5 \pm 94.3$ & $88.2 \pm 12.0$ & $41.6 \pm 4.0$ & $186.5 \pm 11.7$ & $451.1 \pm 26.6$ \\
\hline \multirow[t]{2}{*}{ Control II!* } & $0 \mathrm{wks}$ & $445.5 \pm 76.4$ & $89.7 \pm 17.0$ & $45.5 \pm 4.1$ & $191.1 \pm 24.7$ & $396.9 \pm 14.3$ \\
\hline & 8 wks & $449.6 \pm 75.6$ & $91.9 \pm 16.3$ & $45.6 \pm 3.1$ & $191.2 \pm 22.3$ & $455.4 \pm 20.1$ \\
\hline
\end{tabular}

The values given are mean \pm standard deviation.

ACE - Angiotensin Converting Enzyme activity, TC -Total cholesterol, HDL - High density lipoprotein cholesterol, TG - Triglycerides, BW - Body weight.

$\dagger$ Age of rats used in the experiment was 8 wks.

*Age of rats used in the experiment was 14 wks.

Table 2: Percentage changes in serum analytes in casein, curd and whey treated groups when compared to the control group after 8 wks of treatment

\begin{tabular}{lrrrrc}
\hline Experimental & \multicolumn{5}{c}{ Percentage change } \\
\cline { 2 - 6 } groups (I \& II) & ACE & TC & HDL & TG & BW \\
\hline \multirow{2}{*}{ Casein } & $* 4.3$ & 0.8 & 12.0 & 2.45 & -2.96 \\
Curd & $* 3.5$ & $* 7.3$ & 3.7 & 0.7 & 1.9 \\
Whey & 0.7 & $* 5.4$ & 0.9 & 4.5 & 3.2 \\
\hline
\end{tabular}

${ }^{*} \mathrm{p}<0.05$ in the Student t-test was considered as significant.

ACE -Angiotensin Converting Enzyme activity, TC - Total cholesterol.

HDL-High density lipoprotein cholesterol, TG- Triglycerides, BW-Body weight.

Experimental animals were male Wistar rats.

\section{DISCUSSION}

The ACE inhibiting activity of casein, whey and the impact of prolonged intake of curd on lipid profile were investigated in the present study.

Similar variations in the standard deviation for the ACE activity have been reported in other animal and human studies as well ${ }^{15,16}$. On a rat model, standard deviation of $98.2 \mathrm{U} / \mathrm{L}$ was observed in a control group and $46.5 \mathrm{U} / \mathrm{L}$ in the diabetes group ${ }^{15}$, and in a human study a standard deviation of $36.8 \mathrm{U} / \mathrm{L}$ was observed where they suggested the variation may be due to the gene polymorphism of ANG I converting enzyme ${ }^{16}$.
Treatment with casein, curd hydrolysates or whey for 4 weeks did not result in a significant change in any of the parameters studied. This shows that the beneficial effects of casein, whey and curd can be seen only after a prolonged (8 weeks) intake.

Previous in-vitro studies reported that ACE activity can be inhibited by peptides such as Ile-Tyr, Val-Pro-Pro, Lys-Val-Leu-Pro-Val-Pro ${ }^{7}$ and Ile-Pro-Pro ${ }^{5}$. The ACE inhibiting drug captropril is a sulfhydryl containing dipeptide proline ${ }^{10}$. This suggests that peptides present in both the casein and curd hydrolysates may play a role in the reduction of ACE activity of rats fed with casein and curd hydrolysates. 
The cholesterol lowering activity seen in curd hydrolysates and whey treated group may be attributed to the lipolytic action of bacteria present in the fermented milk $\mathrm{k}^{1}$. Thus, the low serum cholesterol observed in the present study may have been due to the production of short chain fatty acids by these bacteria. Short chain fatty acids such as acetic acid, propionic acid, butyric acid ${ }^{17}$ have a feedback inhibition on the HMG CoA reductase enzyme which regulates the rate limiting step in the cholesterol synthesis $^{17,18}$.

The rats were housed under standard cages. This may have restricted their movement which would have been a possible cause for lower HDL contribution in these animals. It has been shown, about $60 \%$ of the serum total cholesterol is contributed by the HDL cholesterol and $30 \%$ by the LDL cholesterol in rats, in comparison to $30 \%$ from HDL and $60 \%$ in the form of LDL in humans ${ }^{19}$.

The practitioners of folk medicine in Sri Lanka had been advising their patients with high serum cholesterol, to avoid regular intake of curd and yoghurt. However, this study shows that long term consumption of curd by adults, which is comparable to daily intake, decreases the cholesterol level in rats.

The present study suggests that the long term intake of casein helps to inhibit the ACE activity without any significant differences in the lipid profile, and the long term intake of curd inhibits the ACE activity as well as reduce the serum cholesterol. Further studies with other animal models and human subjects are necessary to recommend the health benefits of milk proteins and curd for man.

Casein and curd hydrolysates have a potential to reduce the ACE activity in Wistar rats. Moderate intake $(80 \mathrm{~g} /$ day $)$ of curd may favour the reduction of the total serum cholesterol and ACE. This suggests that casein and curd could be of value as an ACE inhibitor, and curd and whey can be recommended in the management of hypercholestrolaemic subjects.

\section{Acknowledgement}

The authors wish to acknowledge the financial assistance by the National Science Foundation (NSF/Sch/2004/03) and Academic Students Affairs Publications ASP/6/RE/2003/09).

\section{References}

1. Knut J.H. (2001). Probiotic bacteria in fermented foods: product characteristics and starter organisms. American
Journal of Clinical Nutrition 73(suppl): 374S-94.

2. Bordin G., Corderio R.F., Calle de la B. \& Rodriguez A.R. (2001). Identification and quantification of major bovine milk proteins by liquid chromatography. Journal of Chromatography A 928: 63-76.

3. Ballin N.Z. (2006). Estimation of whey protein in casein co-precipitate and milk powder by high performance liquid chromatography quantification of cysteine. Journal of Agriculture \& Food Chemistry 54: 4131-4135.

4. Nakamura Y., Naoyuki Y., Sakai K., Akkira O., Yamazaki S. \& Takano T. (1995). Purification and characterization on Angiotensin 1- converting enzyme inhibitors from sour milk. Journal of Dairy Science 78(4): 777-783.

5. Maeno M., Yamamoto N.\& Takano T.(1996). Identification of an antihypertensive peptide from casein hydrolysate produced by a proteinase from Lactobacillus helveticus CP790. Journal of Dairy Science 79(8): 1316-1321.

6. Yamamoto N., Masafumi M. \& Toshiaki T. (1999). Purification and characterization of an antihypertensive peptide from a yoghurt- like product fermented by Lactobacillus helviticus CPN4. Journal of Dairy Science 82(7):1388-1393.

7. Fugslang A., Nilsson D. \& Nyborg C.B.N. (2002). Cardiovascular effects of fermented milk containing angiotensin -converting enzyme inhibitors evaluated in permanently catheterized, spontaneously hypertensive rats. Applied and Environmental Microbiology 68(7): 3566-69.

8. Abubarkar A., Saito T., Kitazawa H., Kawai Y. \& Itoh T. (1998). Structural analysis of new antihypertensive peptides derived from cheese whey protein by proteinase K digestion. Journal of Dairy Science 81: 3131-3138.

9. Brown N.J. \& Vaughan D.E. (1998). Angiotensinconverting enzyme inhibitors. Circulation 97(14): 1411-1420.

10. Tripathi K.D. (2003). Essentials of Medical Pharmacology. $5^{\text {th }}$ Edition. pp. 445-472. Jaypee Brothers Medical Publishers (Pvt) Ltd, New Delhi, India.

11. Alm L. (1982). Effect of fermentation on lactose, glucose, and galactose content in milk and suitability of fermented milk products for lactose intolerant individuals. Journal of Dairy Science 65(3): 346-352.

12. Mizuno S., Nishimura S., Matsuura K., Gotou T. \& Yamamoto N. (2004). Release of short and proline-rich antihypertensive peptides from casein hydrolysate with an Aspergillus oryzae protease. Journal of Dairy Science 87(10): 3183-3188.

13. Chandrika U.G. (1999). Glycosylation of bovine (alpha) lactalbumin. M. Phil Thesis. pp.30-31. Massey University, Newzealand.

14. Gordon W.G. \& Kalant E.B. (1978). Proteins of milk. In: Fundamentals of Dairy Chemistry, (Ed. J.A. Webb) $2^{\text {nd }}$ Edition. pp. 87-118, The Avil Publishing Company Inc., Philippines.

15. Bor M.V., Elmali E.S. \& Altan N. (2003). Serum angiotensin converting enzyme activity in streptozotocin induced diabetic rats. Trukish Journal of Medical Science 30(5): 311-313. 
16. Delanef F.L. et al. (1998). Plasma concentration, kinetic constants, and gene polymorphism of Angiotensin 1 - converting enzyme in centenarians. Clinical Chemistry 44(10): 2083-2087.

17. Hara H., Haga S., Aoyama Y. \& Kiriyama S. (1999). Shortchain fatty acids suppress cholesterol synthesis in rat liver and intestine. The Journal of Nutrition 129: 942-948.
18. Robert K.M., Darly K.G., Peter A.M. \& Victor W.R. (2000). Harper's Biochemistry. 25 ${ }^{\text {th }}$ Edition. pp. 260-669. Prentice-Hall International Inc., New Jersy, USA.

19. Gwynee J.T., Mahaffee D., Brewer H.B. \& Ney R.L. (1976). Adrenal cholesterol uptake from plasma lipoproteins: regulation corticotrophin. Proceedings of the National Academy of Science, USA 73(12): 4329-3. 